\title{
Morphological Adaptation of Anglicisms in the Albanian Press
}

\author{
Irena Pata Kapo \\ $\mathrm{PhD}$, University Of Tirana, Albania
}

\begin{abstract}
The flux of Anglicisms in Albanian language is a phenomenon of the last two decades. Similarly to many other European languages Albanian has been under the influence of English language for some time now and in a wide range of areas of life, study, etc. This paper, which is only a part of the author's research study of Anglicisms' 'behavior' in Albanian, aims at analyzing the morphological adaptation of English loan words in Albanian; their grammatical categories, how they adapt to Albanian grammatical system and the changes they go through in order to 'survive' permanently, stay and be used temporarily by Albanian speakers or leave the Albanian lexis, due to their equivalents already existing in Albanian or to the high level resistance Albanian language poses to them. This analysis is performed referring to the counterpart categories of these loans in Albanian, thus adaptation of nouns and how does their declension, gender and number fit within the noun category in Albanian, adaptation of adjectives, verbs, adverbs, etc.; a part of this paper analysis are also the acronyms borrowed directly from English, compounds as well as some forms of word formation under the influence of English language.
\end{abstract}

Keywords: morphology, adaptation, Anglicisms

\section{Introduction}

The influence of English language on Albanian language, a phenomenon of the last two decades, seems to be drawing the linguists' attention. A corpus of 511 Anglicisms bears witness to the active life of these English borrowings in the Albanian press after the 1990s.

A generally positive attitude is held towards the use of Anglicisms in the Albanian press language in order to fill the lexical gaps with words and phrases denoting new concepts and notions or carrying extra connotative meanings rather than their use to duplicate existing lexical units in Albanian, in an effort to preserve the Albanian language identity in this globalization epoch of ours, thus contributing to the linguistic and cultural heritage of the country.

\section{Literature Review}

One of the primary conditions for two languages to exhange lexical items between each other is the geographical proximity, but this is not the case with the two languages in question, Albanian and English language, i.e. referring to the countries where they are basically spoken. If we refer to the history of the written Albanian language, English words have been borrowed in Albanian since its first publications, starting from the middle of XIX century and on. These publications include school texts as well as newspapers published in the two languages such as Dielli, Laboremus etc. Two other factors that promoted further the borowings from English were the opening of the Albanian-American Institute of Kavaja and the establishing of the American "Harry Fultz" High School in 1925.

In the XX century, after the turmoil the two World Wars brought in the region, and in Albania, in comparison to other countries Albania somehow lost contact with English language and culture due to the communist regime established in this country as soon as the war came to an end. Regardless the isolation, English language continued to be a priority and the first foreign language taught in most of the Albanian schools, and Albanian society had a very positive orientation towards English language and culture, even though hidden and covered from the fear of the different forms of punishment established by the regime, and being more oriented towards English culture, cinema, music, movies and sports originating from the English speaking countries. 
After the 1990 (the year that marked the change of the systems in Albania), the Euro-atlantic integration of the country became the real issue for our country and as a result the contacts and relations with many international organisms (OSCE, Council of Europe, NATO, etc.) increased, bringing to another development stage the English borrowings in Albanian language. The opening of the borders was not only literal but released the borders of Albanian culture, politics, media, etc., to have a free exchange with the 'other world' and particularly the global language, English language. It still continues to be a priority in the Albanian education and is one of the main conditions to be met for providing a job position.

There are cases when Anlicisms in the press are used to express a word recently adopted in Albanian language, often due to its shortness in comparison to the Albanian counterpart word; there are also many other cases in which Anglicisms are used extensively although in Albanian already exists a word/translation for that, replacing the Albanian word in many contexts: workshop and seminar. The reason beyond that lies in the tendency of the speakers to sound -'more modern' in their talk; in other cases Anglicisms are completely adapted to the Albanian orthography and pronunciation of the Albanian language, as it is the case with menaxher.

While in the other countries of Europe, the study on Anglicisms and their features and behavior in different European languages dates back since the middle of the twentieth century (with highly recognized researchers and linguists as Rudolf Filipovic, Manfred Görlach with his Dictionary of European Anglicisms, Ivan Klajn, etc., in Albania this is rather a new phenomenon with sporadic studies from Rajmonda Këçira, Xhevat Lloshi, etc; whereas studies from the Kosovo researchers and linguists date a lot earlier and are more extensive with names like Vesel Nuhiu, Ismail Mehmeti etc.

In the Dictionary of European Anglicisms, Manfred Görlach includes Albanian language as one of the 16 European languages, whose Anglicisms he has collected. Görlach also refers to the lack of studies in this particular area of linguistics particularly in Albania. The research studies of two Kosovo linguists, that date back to 1980s, have been the source of the data for Görlach and his dictionary, thus without any concrete contribution from the Albanian language institutions of Tirana.

The 1980 Abanian language Dictionary, published by the Albanian Academy of Sciences lists 53 Anglicisms, a best part of which are not included in the 2002 and 2006 edition. The most recent edition, that of 2006, lists 80 Anglicisms out of 48,000 words. 15\% of the corpus of Anglicisms collected from the Albanian press since the 1990 are included in this recent edition.

\section{Methodology}

The basis for the analysis of this research paper was the corpus of 511 Anglicisms collected in the Albanian press from 1990 to 2010, including numerous editions of Albanian newspapers and magazines during this time span, without being limited nor on specific titles, neither on the area they covered.

\section{Results}

Out of 511 Anglicisms collected, $87.6 \%$ were nouns, about $12.7 \%$ adjectives, $4.1 \%$ verbs, $0.9 \%$ adverbs and $1.5 \%$ noun phrases.

\section{Discussion}

The British linguist T. Hope describes the real nature of loans during the transferring process as characterized by: "the loss of their morphological and semantic transparency"1. In fact, the loss of the morphological and semantic transparency of the loans depends on the tendency and on the path the loans follow before they penetrate into the target language, but it also depends on the "willingness" the target language has to welcome them.

The adaptation of a loan depends on the need to express a certain meaning and on the efficiency it has in conveying such a meaning.

What is mostly borrowed from English are names of objects or other phenomena. Thus, there are more nouns than other parts of speech listed in the loan group. Often a verb can be replaced by a nominal phrase but the opposite is rare. ${ }^{2}$

\footnotetext{
${ }^{1}$ Barbara A. Fennell, A History of English, Blackwell Publishing, 2008, p. 173

2 Rudolf Filipovic, The English Element in European Languages, Anglicisms in Croatian, 1990, extracted on 27.9.2006, http://mahazu.hazu.hr/LingResIn/FilRuPr.html
} 
Adjectives are generally less necessary since they serve to emphasize one of the qualities regarding an object, phenomenon, etc. rather than to define new concepts.

The English language is a minimally inflected language compared to many other Indo-European languages, especially to the Albanian language; this can be seen in the grammatical category of gender, in having no adaptation of adjectives to nouns, as adjectives are not inflected to adapt to nouns. The case category has almost disappeared, being more limited to the forms of the pronouns ${ }^{1}$ and the indicators of plurality have become more regular. As a result, the language is more based on such 'tools' as the word order in order to show the relations between words.

According to Filipovic the adaptation of loans on the morphological level, called transmorphemization, has three degrees: a) zero transmorphemization (when the loan undergoes no change, i.e. it takes neither a prefix nor a suffix in the target language): fashion, bar, doping etc., b) partial transmorphemization (when the loan preserves the prefix/suffix of the source language: spiker, selektor, reporter etc.), c) complete transmorphemization 2 : skanoj, trendi, çatoj etc. Let us further see which of these three degrees the Anglicisms in our glossary belong to, i.e. whether their transmorphemization is more of the complete, partial or the zero type, by analyzing them based on their respective part of speech.

\section{Adaptation of Nouns}

\section{Gender}

In the Albanian language nouns are of masculine and feminine gender, while neutral gender has shrunk with the passing of time. There are some external elements that assist us in determining the gender in Albanian. It is interesting to study the reaction of loans to the gender of nouns. In English, though, gender is not a feature of nouns themselves, as it relates directly to the meaning of nouns, with particular reference to biological sex. The majority of the noun loans, adapt imminently to the two gender system in Albanian, depending on the word endings.

Often the gender of the loans is determined by the final sounds/phonemes of their stem. These nouns are integrated into masculine gender depending on the pronunciation pattern. Thus, noun loans ending in consonants are included in the masculine gender category: antidoping- $u$, aneks-i, bekgraund-i, çarter-i, draft-i, impakt-i, lifting-u, lobing-u, parking-u, shoping-u, showbiz-i, t-shirt-i, raund-i etc. Similarly aftershave, bite, dance, deadline, dendi, derbi, DJ, game, hobi, hokei, home page, hot line, jive, joint venture, mouse, mobile, party, puzzle, sex gate, single, site, skype, slide, uiski, u-tube, video game, website belong to the masculine gender and to the category above. As the examples show, most of them preserve their English spelling and pronunciation, and are integrated into the masculine gender structure of Albanian (aftërsheiv, pazëll, seks geit etc.).

Out of 448 noun loans in the glossary, 368 end in consonants and are integrated into the masculine gender category.

The noun loans of the glossary ending in vowels are included in the feminine gender category: xhudo, tekno, tatu, soap opera, rege, regbi, kompani, koka-kola, logo, ekstazi, hipi, masmedia, barbekju dhe privaci; also the nouns ending in unstressed -ë: audiencë, performancë, korporatë, ligë, stjuardesë, striptizë;

The gender of ompounds is determined by the second/last component: task forcë, overdozë, telekonferencë, videokamerë, toplistë, renklistë, rockbandë, seks bombë, databazë. These categories appear in the glossary with the -a marker of the feminine gender (telekonferenca, task forca, etc).

Several acronyms have both genders based on their pronunciation. They are categorized as feminine, because, as acronyms, when read, they are morphologically marked for feminine, following the gender of the word "shkronja" (letter) in Albanian, where the -ja ending is the feminine gender indicator in this case: WC-ja, SMS-ja, PC-ja, R\&B-ja, PhD-ja, GDPja, HD-ja, MMS-ja, CV.ja, CD-ja, DVD-ja and IT-ja.

Regarding the categorization of a noun as of a specific gender, in some cases, the lexical meaning of the word is taken into consideration as well. This refers to the relation between gender and sex. In agent nouns (of humans and animals) the gender is closely linked to the biological sex. This makes the gender of agent nouns not simply a grammatical category, but also a lexico-grammatical category, because an element of the lexical meaning of the word (the sex of the agent) is

\footnotetext{
${ }^{1}$ Fatmir Agalliu etc., Grammar of Albanian Language, Morphology, Academy of Sciences of the Republic of Albania, 2002, p. 111

2 F. Agalliu, etc, Grammar of Albanian Language, p.115
} 
reflected in the grammatical context (by being included in one or the other gender). In some of the noun loans (noun agents) in our glossary, these two elements (feminine gender ending and masculine lexical meaning) contradict each-other, as is the case with biznesmen referring to men involved in business activities and biznesmene, which, by taking the feminine gender ending $-e$, becomes feminine, referring to women involved in business activities, thus, bearing two contradicting linguistic indicators. The same goes for other words: barmen - barmene, kaubojs - kaubojse, kongresmen - kongresmene, narkoman - narkomane, supermen - supermene, xhentëllmen - xhentëllmene.

The loan miss ("a title given to the winner of a beauty contest in a particular country, town, etc."), which is feminine, due to the final consonant ending -s, becomes masculine in Albanian, based on its pronunciation: Miss-i i parë shqiptar... Formally this noun loan is masculine, but lexically it is feminine.

In conslusion, 396 nouns (88.3\%) out of a total of 448 words in the glossary are of masculine gender, while 45 nouns or about $10 \%$ belong to feminine gender.

\section{Declension types}

Nouns are divided into four declension types in the Albanian language. ${ }^{1}$ The Anglicisms in the glossary can be classified according to the criteria of each of the declension types, except the fourth declension which, in Albanian, includes the neutral gender nouns, and our glossary lists none of the type.

First declension includes the majority of masculine nouns, which in the nominative case, singular form, indefinite form, end in a consonant, except those ending in $k, g$ and $h$ : akses - $i$ (definite form, singular) - nominative case, akses -in (definite form, singular) - accusative case, të aset -eve (definite form, plural) - genitive case, audit -it (definite form, singular) dative case, etc.

Among the nouns of the first declension type in the glossary of Anglicisms there are some examples of Anglicisms that belong to the "zero transmorphemization" type, according to the 'morphological adaptation criteria' established by Filipovic. In their spelling they do not bear the respective endings of the declensions, whereas when spoken the opposite occurs:

... u transferua te nightclub..., ...kanë nxjerrë nga knock out Utahh Jazz...,...nga homepage..., ...java pushtohet nga action, "byte" realizuan gjithë...,"By-pass", ndërhyrjet e famshme...,_Firmat apo joint ventures..., Disa cowgirl...,...duke e vënë theksin tek webcam.... merren me gossip, furtunën e impeachment, etc.

The second declension includes a limited number of masculine nouns, which in the nominative case, indefinite, singular form, end in $k, g, h$ or in stressed vowels2: e ajsberg-ut - genitive case, ajsberg-ëve (plural form) - dative case; ajsberg accusative case, ajsberg - ablative case; facebook-u (definite, singular) - nominative case, e facebook-ut - genitive case, facebook - accusative case, etc., examples which are easily identified in the glossary.

The Anglicisms miting, modeling, parking, playback, presing, smog, streçing, and shoping are also included in this declension.

The examples of the second declension that bear no endings are:

ylli i bodybuilding, kampionatin e Bowling, 68 hot dog, mes wrestling dhe rugby, airbag (për shoferin), (6) airbag, (me një) click, tek një klik, nëpërmjet rafting

The third declension type includes all the feminine nouns and some masculine nouns, that denote agent nouns. ${ }^{3}$ Here are included a number of Anglicisms in Albanian such as:

audiencë-s (Dat., definite, singular), audiencë-n (Acc., definite, singular);

të korporatë-s (Gen.), korporatë-s (Dat.),

e performance-ave (Gen.), performancë-n, performancë (Acc.)

\footnotetext{
1 F. Agalliu etc., Grammar of Albanian Language, p. 115

2 F. Agalliu etc., Grammar of Albanian Language, p. 89-94

${ }^{3}$ F. Agalliu etc., Grammar of Albanian Language, p. 96
} 
i privacy-së (Gen.), privacin-ë (Acc.),

një tattoo (Nom.), tattoo-në (Acc.),

të top-list-ave (Gen.), top-list-at (Acc.),

videokamer-at (Nom.), videokamerë-n (Acc.),

The examples that do not bear the respective endings of this declension, i.e. those belonging to the zero transmorphemization type, are: Ekstazi, droga e diskove..., mbi task force, mes wrestling and rugby.

\section{The grammatical category of number}

This grammatical category of nouns is related to their lexical meaning. This also explains why some nouns are only used in the singular or in the plural. ${ }^{1}$ The Albanian language has special endings for plural forms which are distinguishable from singular forms.

Thus, referring also to the examples found in the written press, two of the loans in the glossary preserve the same stem both in singular and in plural, following in this way one of the rules of the Albanian language morphology, according to which: "All the feminine nouns ending in unstressed $-e$, unstressed -0 and one of the stressed vowels $-i,-a,-0,-u,-e$ "2 have the same stem in singular and in plural: logo, top-modele.

One of the two ways to form the plural special stem in Albanian is via the use of suffixes added to the singular stem. The plural suffixes that occur more often among the loans of the glossary are:

-e (the nouns ending in consonants like $t$ and $d$, as well as other consonants):

abstrakt-e, anekse, asete, bare, billborde, bojkote, bokse, bonuse, brande, çipe, dezajne, drafte, eksese, eksporte, fast foode, faulle, flirte, gejme, grante, hite, hobe, indekse, inpute, klone, koktejle, lobe, lote, markete, etc.

-ë (mainly nouns of masculine gender):

ajsbergë, aplikantë, badigardë, barmenë, bigë, biznesmenë, editorë, gangsterë, huliganë, kameramanë, kaubojsë, killerë, kllounë, kongresmenë, kontenierë, liderë, manaxherë, nokdaunë, partnerë, sponsorë, supermenë, xhentëlmenë, rockstarë.

$-a$ (the majority of feminine nouns ending in the unstressed $-\ddot{e}$, many masculine nouns ending in consonants):

bannera, bestsellera, databaza, fansa, gola, hackersa, e-maila (Kjo fushatë përfshinte kërcënime dhe emaila të drejtuara mua personalisht - She., 23.2.2010, 16), mastera, performanca, postera, servera, singëlla, snoba, stjuardesa, tonera, toplista, trailera, uesterna.

Some loans ending in -i preserve the same form in the singular and in the plural, such as janki, hobi, derbi etc.: një derbi one derby (singular), dy derbi - two derbies (plural). ${ }^{3}$

The plural form of some Anglicisms is acquired through changing the sounds and with suffixes ${ }^{4}$ such as: blog - blogj-e, kamping - kampingj-e, miting - mitingj-e.

A separate group includes words that have two forms of the plural: bos-ë - bos-a, kompjuter-a - kompjuter-ë, tabloid-e tabloid-ë, workshop-e - workshop-ë.

Finally, another phenomenon observed within the plural category of nouns is the one where an Anglicism bears the plural indicator of the English and the plural indicator of the Albanian or to put it differently, the stem of the English plural form

\footnotetext{
${ }^{1}$ I. Mehmeti, A morphological and Semantic Analysis of the Adaptation of Anglicisms in Albanian, (The English Element in European Languages, Vol 2, Rudolf Filipović), p. 33

2 F. Agalliu etc., Grammar of Albanian Language., p. 97

${ }^{3}$ R. Këçira, Anglicisms in Albanian: A Direct and Mediated Language Contact Phenomenon, Graz, English Institute, 2005, p. 199

${ }^{4}$ Shumë nga "bookmaker"-at e mëdhenj kanë përfaqësues të tretë... (She., 18.1.2013, 26)
} 
serves as the singular stem of the English loan in Albanian. Rajmonda Këçira, in her dissertation, uses the term 'double plural'1: xhins-e, hackers-a, shots-a, fans -a, kaubojs-a, skorpions-a, bookmakers-a etc.

Some of them appear in the press in two plural forms, one of which reflects a full or partial adaptation of the Anglicism to the plural form of the Albanian language, e.g. haker-a (full), bookmaker-a² (partial), and the other 'the duplication' of the plural indicators of both languages: hakersa ${ }^{3}$.

\section{The grammatical category of Case}

The extensive use of loans in many lexical areas and the increase in their frequency has led to the loan nouns being used in many different syntactic structures and in several forms, thus, in all the cases the noun category bears in the Albanian language. The collected glossary of Anglicisms illustrates best the variety of the forms the anglicisms are found in the printed press, expressing in this way the different relations they establish with the other parts of the sentence.

Nouns in Albanian have five cases: nominative, genitive, dative, accusative and ablative. ${ }^{4}$

The nominative case generally marks the subject of the sentence, part of the subject complement, the appositive and the vocative. The following are examples taken from the glossary of Anglicisms:

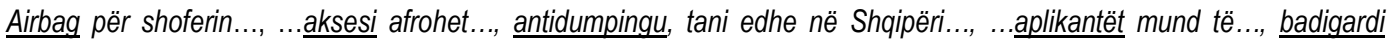
afrikan....,etc.

- (subject complement) ...protesta e 21 dhjetorit është një test që duket se e majta ka vendosur ta kryejë (Kl, Nr 541, p. 5)

- (appositive) Elton John, fans i Leon Russell,... (GSH, 23.10.2010, pg. 4).

Or

Grekët, sanduiç mes parasë dhe terrorizmit. (Al, 26.3.2004, pg. 18),

(vocative) More Reis, mos kanë harruar të të sjellin ndonjë bukuroshe, se ti helbete je showman dhe ku i dihet mbase gjallërohesh! (Spe., 10.2004, pg.28), etc.

The prepositions $n g a$ and $t e(k)$ are indicators of this case as well:

plotësuar nga aplikantët, ...të udhëhequr nga bomberi i tyre..., ...ikën nga bordi..., ... nga faulli..., ...nga feedback-u..., ...besonin te gangsterët..., etc.

The nominative case appears in two forms, definite and indefinite. As it is seen, in the examples cited above most of the Anglicisms adapt to the respective case and form similiar to all the nouns in the Albanian language, with the respective endings: $-i,-e,-t e \ddot{e},-t,-u,-j a$. $-a$, -ë or with no ending, as is the case with nominative, indefinite form (tek një laptop, nga një link etc.). Even those Anglicisms that have preserved their English spelling (chat-et, e-mail-i, feedback-u, face book-u etc.), take their respective ending as well (SMS-të, VIP-a etc.) but, in the cases when the endings are not reflected in their spelling, it is very likely for the speakers to attach these endings to these nouns in their speech (CV e presidentit...).

The genitive case is mainly used with nouns in different modifying functions. It is used to show relevance, to characterize an item, etc., to express the relation of the part to the whole, etc. The glossary lists many examples of Anglicisms in the genitive case:

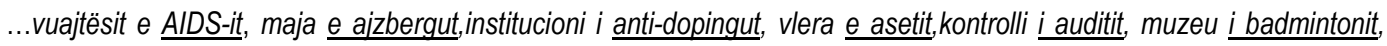
kaloritë e një cheeseburger-i, etc.

\footnotetext{
1 Pasi ai e prezantoi projektin në një takim në Chaos Computer Club, që është edhe grupi më i rëndësishëm i hakerave në Gjermani... (Shq., 23.8.2011, 5); Ai pershkruante se si hakerat dhe frikersat e telefonave kishin zbuluar nje menyre per te kryer telefonata pa pagese (Pa., 5.6.2012, 20)

2 F. Agalliu etc., Grammar of Albanian Language., p. 107

${ }^{3}$ F. Agalliu etc., Grammar of Albanian Language, p. 109

${ }^{4}$ F. Agalliu etc., Grammar of Albanian Language, p. 344
} 
There are some cases of Anglicisms that bear the attributive marker of the genitive case, according to the respective gender and form, but they do not take the typical ending of the genitive case (at least in their written form):

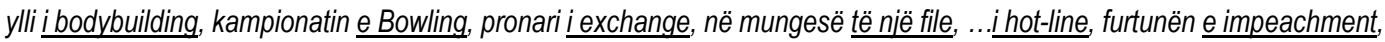
patentën e sex-symbol.

The dative case. It regularly denotes the indirect object: the item or the person, to whom the action is directed, with impersonal verbs, the person that experiences a physiological state, the person or item something belongs to, etc. ${ }^{1}$ The following Anglicisms appear in the dative case, with the respective functions listed above:

audiencës nuk do t'i flasë, i mbyll derën auditit, t'i jepte ndihmën e parë bodyguardit, kushtuar biznesit, u tha kongresmenëve, që i bëhet kompanisë,.

The accusative case denotes: the object that receives the action conveyed by a transitive verb, a feature of the object denoted by the direct object, quantity and measure, etc. Different meanings are conveyed also by the use of prepositions like në, mbi, nëpër, për, mbi, me and pa.

me AIDS, me dopjo airbag, të kenë akses, paraqiten në aneksin, 350 aplikantë, të shohësh audiencën, kthen auditin, liroi ish-bodigardin, etj.

The ablative case can be used with verbs and participle (ing-, ed-) adjectives, also with nouns, denoting a cause, means, place, time, etc. This case, too, recognises the use of its respective prepositions such as ndaj, buzë, afër, prapa, pranë, mbas and para.

locioneve aftershave, përplasja ajsberg, çështje "baitesh", mes "bigëve", mes drejtuesve dhe bordit, të fiksuar pas chat-it, nëpërmjet chat-it, pas çekut, pas faullit, drejt finishit, sipas tabloidëve, larg th-shirt-eve, prej xhinsi etc.

Regarding the use of Anglicisms that are not adapted or not integrated into the Albanian language, it is noticed that the case ending is presented by a hyphen followed by the respective ending, based also on the pronunciation of the word in Albanian: pamjen e një twinset-i, mbretëresha e talkshow-t, kërcimit të jazz-it, dhunimi i privacy-së etc; or there are also cases when the endings are non-existent, such as the cases listed above in the genitive case: $y$ lli $i$ wrestling, $y l l i ~ i$ bodybuilding, patentën e sex-symbol, femra të showbiz, në saj të disa single, mbi të vërtetat e show business etc. The last cases pose difficulties for the readers, regarding their assimilation due to their failure to adapt in the written Albanian but also due to the morphological features.

\section{Adaptation of Adjectives}

About $12.7 \%$ of the Anglicisms in our glossary belong to the category of adjectives. Adjectives in Albanian are of two types: with an attributive article or without one while the adjective loans do not have an attributive article:

out, flesh, high-class, high-tech, hard, hot, horror, casual, cross-border, non stop, part-time, single, sexy/seksi, snob, pushup, porno, stand-by, unisex, wanted, trendy/trendi, topless, bold, senior.

Considering that the adjectives acquire the gender and the number of the noun they modify, their endings adapt to the noun they modify. This adaptation is achieved by changing the article or via feminine endings like $-e$; in plural, there is a change in the article from i/e to $t$, or with the ending - ë. Referring to the examples from the glossary it is identified that the adjective loans have a low degree of adaptation in Albanian: out of 65 adjectives in total, only four of them acquire the respective endings of this grammatical category depending on the nouns they modify:

$$
\begin{aligned}
& \text {...video hard / skena hard... } \\
& \text {...foto hot / vajza, performanca hot... } \\
& \text {...veshje / modele casual... } \\
& \text {...punë / protesta non stop... }
\end{aligned}
$$

${ }^{1}$ I. Klajn, Influssi Inglesi nella lingua italiana, Firence, Olschki, 1972, p. 71 
...politika unisex / motive unisex...

On the other hand, we have some examples of adaptation:

......fansa snoba..., ...grua snobe...

...aftësi menaxheriale...

...reformë bipartizane...

Most of the adjectives preserve their English spelling and pronunciation in the source language when used in Albanian, except sexy and trendy, which appear in both forms, in their English and in their Albanian form (the adapted version): seksi and trendi.

With regard to the adjectives' degrees, the adjective loans in our glossary are qualitative adjectives ${ }_{2}$ the semantics of some of which allows the expression of the respective quality in different degrees, following the Albanian system/degree indicators (...ka fituar çmimin "Vajza më hot e vitit" nga zgjedhjet e adoleshentëve (Kj, 11.8.2009, 16); Flokët e sfilatave dhe pesë idetë për të qenë më trendy (Spe, 3.2005, 49); Tre tipa pak hard (KI, 9.2.1998, 36), ...këngëtarja më e klikuar ...(Pa., 13.12.2012, 4).

\section{Adaptation of Verbs}

$4.1 \%$ per cent of the glossary of Anglicisms that belong to the category of verbs are, mostly English loans adapted to the verb system of the Albanian language. Suffix verb- formation is the most productive type in the derived verbs group ${ }^{1}$ and this is also typical of the rest of the verbs' group part of the glossary. A word formation of this type is distinguished by the typical Albanian suffix -oj in the verb Anglicisms of the glossary: adres-o-j, afekt-o-j, çat-o-j, dribl-o-j, implement-o-j, klik-o$j$, kros-o-j, lob-o-j, menaxh-o-j, monitor-o-j, start-o-j, test-o-j, stop-o-j. As it can be seen, these verb Anglicisms belong to the first conjugation from three of the kind that exist in Albanian.

The same occurs also with the adjective Anglicism snob which in Albanian appears as a verb 'snoboj' while this word does not recognize this category in the English language (i.e. in the verb category) (which, in fact, leads to this word being listed under the pseudoanglicisms category):

Peqinasit 'snoboinë' kupën, presin merkaton e dimrit (PaSp, 13.12.2012, 6)

The verb download is never found in the adapted Albanian version in the examples from our glossary, resulting as zero transmorphemization element: bearing no identifying suffix, but, in this case, the grammatical category of this word is determined by the context.

\section{Adaption of Adverbs}

There are few adverbs found in the grammatical category of adverbs: full time, live, non-stop, out, topless. In Albanian they are identified as such only by referring to their position in the sentence and by the relationship established with the other parts of speech. Based on the context in which they are used it can be said that these adverbs appear to be mainly adverbs of manner:

Gratë festojnë 8 marsin, "full time" për guzhinjerët e restoranteve (Al, 9.3.2004, 12); Dy artiste nga dy drejtime krejt të kundërta këndojnë live në Tiranë, në të njëjtën ditë, me 4 korrik (She, 26.6.2007, 32); ...duke iu lutur non-stop kirurgut... (KI, 7.12.2007, 5); Dhe madje për t'u çliruar nga kilet e tepërta rehabilitohet bifteku, i dekretuar "out" në vitet '90 (Kl, 16.1.2000, 50); Kohë më parë, e kishin fotografuar toples ndërsa përqafohej me të fejuarin e saj $($ She, 8.9.1999, 19) etc.

Their zero level transmorphemization is justified not only by their spelling, meaning and pronunciation preservation in Albanian, but also by the fact that they receive no identifying suffix that belongs to the adverbs category. Unlike adverbs in Albanian and based on the examples identified up to now, the English adverb loans do not bear the degree category.

${ }^{1}$ R. Filipović, Semantic Extension in Adaptation of English Loan-Words in Serbo-Croatian, Studia Romanica et Anglica, zagrebensia, 2526, December 1968, p 118 
Considering that five of the adverbs listed in the glossary fully preserve their English spelling, it can be concluded that their level of adaptation in Albanian is low.

\section{Acronyms}

This category includes integral loans named as original English symbols. They are pronounced as sequences of letters : WC, OK, SOS, AIDS, CD, CV, DJ, DVD, GDP, HD, HIV, MMS, MP3, PC, PhD, R\&B, SMS, USB, USD, VIP, UFO, etc.

Other acronyms that preserve the English spelling but are pronounced according to the Albanian system are: WC, AIDS, HIV, MMS, SMS, MP3, USB, USD, VIP.

There are other cases of English acronyms and symbols, such as $O K, C D, C V, D J, D V D, G D P, I T, P C, P h D$ and $R \& B$, which preserve not only the spelling of the source language, but also their pronunciation (although CV is Latin, Curriculum Vitae, in Albanian it is pronounced as in the English language [si vi]).

In the list of the acronyms found in the glossary, a good part of them are used as nouns, except $O K, R \& B$, VIP, which appear in the function of nouns and adjectives, and a few as adverbs; ...infermierja VIP..., ...emra VIP..., ...çdo gjë është OK..., muzika R\&B..., ...rryma R\&B etc.

The majority of these acronyms serve their function as nouns, bearing all its features, the number, the case, the gender and the form, as it is illustrated in the examples from the glossary:

Por në fakt, gjithçka lidhet me pozicionin tim si individ dhe me CV-në time professionale (Kj, 4.6.2004, 3); Pa ndjeshmërinë tënde ...ne do të kishim mbetur në padijen më të thellë për ankthin që përjetojnë vuajtësit e Aids-it dhe HIV-it... (She, 27.9.1999, 17); ... që mes të tjerave ka kompletuar tërësisht punën e tij mbi CD-në e gjashtë si solist (Kj, 1.6.2004, 11); Defiçiti buxhetor mbulon 9.1\% të GDP-së (Kj, 23.1.2002, 17), etc.

Although the majority of these acronyms are used in the printed press in the international level, they are included in this study, because in their use in Albanian they carry many of the English elements/indicators, in their spelling or meaning, and especially in the way they are pronounced. Thus, such acronyms can be classified as real/pure Anglicisms.

\section{Compounds}

The semantic and lexical entities, consisting of more than one word, but carrying the meaning of one lexical unit are the ones included under the compound/locutions term. The glossary lists several examples: after shave, best seller, black out, broad band, check-up, check in, duty free shop, exit poll, eye liner, fair play, fan club, fast food, full time, joint venture, call center, happy end, hard disk, hard rock, heavy metal, high class, high definition, high-tech, hit parade, home page, etc.

The use of loan compounds, in many European languages where English language has a considerable impact, is characterized by ellipses or elliptical forms, i.e. the sense of the second part of the phrase is transfused into its neighbor, which then acts for the complete construction, after the second part has been dropped through ellipses, a phenomenon that is not found in Albanian. For instance, the use of similar shortened forms is also found in Italian, French, ${ }^{1}$ German, Serbo-Croatian², etc. In Albanian we often find such words as "Kohët e fundit ai ka hapur një fitness" (meaning: Recently he has opened a fitness center, thus using fitness instead of fitness center; or "Këtë parfumin e kam blerë në një duty free" (meaning: I bought this perfume in a duty free shop), using the English adjective duty-free, part of the compound duty-free shop, as a noun, bearing the meaning of the whole compound; there also other cases such as: flesh - news flash, çarter charter plane, body - body stocking, folk - folk music/dance, house - house music, metal - heavy metal, hostess - air hostess, exchange - exchange office, country - country music, master - master degree, etc.

\footnotetext{
${ }^{1}$ R. Lilo, Third Seminar on: "Loans in the Standard Albanian", University of Tirana, Faculty of the Foreign Languages, 2004, Pegi Publishing House, p.. 33

${ }^{2}$ Dhe shfaqet me një dekolte tunduese në festivalin e Tiranës në top-formën e saj 22 vjeçarja Çelo. (GSH, 16.1.2000, 42)
} 


\section{Word Formation}

As mentioned above, the Albanian language recognizes a range of new formations, created by joining English words and Albanian prefixes or suffixes. In his article The foreign pressure and the Resistance of Albanian Language ${ }^{1}$, Raul Lilo classifies loans as promoters of the word formation system, by underlying that such loans are more frequently found in the press language. He considers them mainly as loans with word formation affixes: prefixes and suffixes that mainly appear in individual and occasional creations, a feature of the press language, taking the emotional degree to another higher level. Among the nouns included in the glossary, there are many nouns that are used as nouns and as verbs in the English language, i.e. in the source language, but in Albanian they are mainly used as nouns. However, many of these words, along with many others, have influenced the creation of many new words in Albanian which have an English stem but an Albanian suffix. Thus, the latter can be considered as part of the lexis of the Albanian language with 'equal rights', as it is illustrated below.

One of the word formation cases is the one with the word formation stem of a compound such as top -in English and formë, listë and yje in the Albanian language in the compounds top-formë ${ }^{2}$, top-listë 3 and top-yje . $^{4}$

It is a characteristic of the language of the press to create words for special stylistic purposes, i.e. to give a certain connotation to them, for example the formations with -land 5 to give the idea of the land/property belonging to someone.

The derived nouns with the suffix -im are formed from their respective verbs (startoj, klikoj, etc): klikim6, lobim , etc.

The derived nouns with the suffix -tet, which in most of the cases replace the English nouns ending in -ty. Such cases of adapted Anglicisms include:

facilitet $^{8}$, fizibilitet ${ }^{9}$, etc.

Like prefixes, the suffixes are not borrowed as such, but together with the words they are part of. These words are also motivated in Albanian, if they are used alone or with their word formation stem or when at least two derived words are formed from that same stem, but with different suffixes, e.g.: global and globalizëm, etc.

The suffix -men is used to form pseudoanglicisms, words created in Albanian, which look like English but with no equivalent of theirs in the English language, such as the word bllokmen, definitely not an English word (a word created in Albanian to refer to the people living in a small area of Tirana, very near the center, isolated during the communist regime for the leading polititical class of Albania at that time, as well as their families).

An example of the word formation can also be the adjectives in Albanian formed by English verb stems, with the suffix -ar. (i) klikuar $^{10}$, (i) apdejtuar ${ }^{11}$, i monitoruar ${ }^{12}$ classified fully as adjectices in Albanian, with all its degrees in Albanian, its articles, gender, etc.

\footnotetext{
${ }^{1}$ kënga e tij ishte afruar befasisht në toplistën e çmimeve të nxehta... (KI, 1.9.2000, 45)

2 Ndërkohë edhe top-yjet e tjerë të Formula 1 janë në top-formë. (Al, 14.4.2010, 23)

3 Udhëtim në Pacolliland (Pacolli mbiemri i Bexhet Pacollit është me të kuqe ndërsa land me të zeza) $(\mathrm{Kl}, 15.9 .1999,28)$

Parajsa për ta është edhe ky Anarkiland, që quhet Kamëz dhe Bathore, me flamure kudo, me ndërtesa të lyera plot slogane dhe me rradhë. (Ma, 15.5.2011, 18)

${ }^{4}$ Në bazë të një sondazhi të zhvilluar në internet... fitues del "Tingulli 3nt" me 20.4\% të votave dhe më konkretisht me 582 klikime. (GSh, 13.10.2007, 13)

${ }^{5}$ Njohja e Kosovës nga Arabia, falë lobimit të Shqipërisë. (GSh, 23.4.2009, 1)

${ }^{6}$ Sipërfaqet e zyrave variojnë nga $15 \mathrm{~m} 2$ deri $100 \mathrm{~m} 2$, të pajisura me të gjitha facilitetet. (GSh, 4.8.2004, 28)

${ }^{7}$ Studimi i fizibilitetit dhe përgatitja e projektit i janë besuar firmës "Bechtel". (GSh, 10.12.1997, 2)

${ }^{8}$ Gjithsesi në çdo rast duket se edhe Blunt i pëlqen të koleksionojë të dashura, pasi këto kohë është i klikuar prej tyre. (GSh, 15.7.2006, 7)

${ }_{9}^{9}$ Synimi është që viti 2006 ta gjejë komunitetin e biznesit shqiptar e të huaj që vepron në vend, me një listim të ri, shumë më të "apdejtuar". (KI, 13.8.2005, 6)

${ }_{10}$ Ai është institucioni më i monitoruar nga publiku $(\mathrm{Pa}, 24.1 .2012,9)$

11 "The last house on the left" është ripërpunimi modern i filmit kontrovers dhe shokues të vitit 1972... (VIP, 6.2009, 32)

12 ...duke i dhënë grupit testues mundësinë për të shkruar opinionin e tyre...;...pjestarët e grupit kanë testuar produktet e para...; Qëllimi i kësaj miqësoreje ka qenë testimi i disa futbollistëve të huaj. (Je, 12.2011, 84)
} 
The English loans in Albanian in general have expanded their word formation ranges. Examples that illustrate the expansion of the word formation ranges are the following Anglicisms (there are more examples included in the glossary):

Shok (n) - shokoj (v) - shokues (adj.) $)^{1}$, test - testoj - testues - testim ${ }^{2}$, kros-krosoj-krosim $\underline{m}^{3}$, etc

Similiar to the influence of English on many other European languages, its influence on Albanian language goes beyond the limits defined above. As it is for instance the irreversible integration of some loans into the Albanian language, bearing the endings of Albanian and 'behaving' according to its rules. Thus, for instance, there is the phenomenon of the creation of neologisms: the new words or the new meaning that many words in Albanian acquire under the influence of English language. On the other hand, according to the specifications each language has and according to the historical, political, cultural and social context in which it is spoken, there are structures or compounds recognized and created which acquire a meaning only in the respective language; an example of which is 'copy-paste' which refers to the action of copying something, i.e. to show lack of genuinity for something new that is created, or when used as an adverb: "Teksa i sheh së bashku kupton magjinë e të ndjerit artist dhe vetinë për ta përcjellë atë 'copy-paste' te brezi pasardhës (Paloma, 9.2.2012, 23)".

\section{Conclusions}

The future of Anglicisms in Albania, according to Manfred Görlach who together with Rudolf Filipovic have been two of the most distinguished researchers of Anglicisms in Europe, depends on the country's stability, on the English learning system and on the international communication extent and technological and cultural exchange with the English speaking world. They have also expressed the total absence of relevant literature in Albania. This also justifies the reduced explanation (in quantity as well as quality) of the Albanian data in the Dictionary of European Anglicisms of Görlach.

The prestige of the loans regardless the source language and country, can never be higher than our native language and its cleanness. The objective of this study has been the identification of English loans, their behaviour and their adaptation degree in Albanian language. Many of them have come along with the new inventions, objects and notions of science, technology, music, fashion, etc. Thus let us consider them as complementary to the needs of our language, to fill the gaps we encounter in its lexis. Regulating or putting some order in this gap-filling shall and must be the focus of Albanian linguists.

\section{References}

\section{Books, Single authors}

[1] Bonomi, llaria. (2002) L'italiano Giornalistico. Dall'inizio Del '900 Ai Quotidiani on Line. Firenze, Cesati

[2] Crystal D., (2003) English as a Global Language, $2^{\text {nd }}$ Ed. Cambridge: Cambridge University Press

[3] Fennell Barbara a., (2008) a History of English, a Sociolinguistic Approach, Blackwell Publishing

[4] Fevziu B., (1996) History of Albanian Press, "Marin Barleti" Publishing House

[5] Filipović Rudolf, (1982) the English Element In European Languages, Zagreb

[6] Görlach Manfred, (2002) English In Europe, Oxford University Press

[7] Görlach Manfred, (2003) An Annotated Bibliography Of European Anglicisms, Oxford University Press

[8] Hope T., (1971) Lexical Borrowing In Romance Languages, Oxford, Blackwell

[9] Kapo Irena , (2016) Ndikimi I Anglishtes Në Shtypin Shqiptar Paskomunist, (Impact Of English Language On Albanian Post-Coomunist Press), Monography, Botimet DRITAN, Tiranë, ISBN: 978-9928-184-35-1

[10] Klajn I., (1972) Influssi Inglesi Nella Lingua Italiana, Firence, Olschki

[11] Këlliçi Skifter, (2005) "The Indefinite That Becomes Definite In Albanian Press"

[12] Këçira Rajmonda, (2005) Anglicisms In Albanian: A Direct And Mediated Language Contact Phenomenon, Graz

[13] Land E. Myrick, (1993) Writing For Magazines, Prentice Hall

[14] Mehmeti I., A Morphological And Semantic Analysis Of The Adaptation Of Anglicisms In Albanian, (The English Element In European Languages, Vol 2, Rudolf Filipović)

\footnotetext{
1 ..goli i minutës 56 e realizoi pas një krosimi mjaft të bukur të Rrapajt. (SpoEks, 16.1.2012, 6)

2 B. Vertecchi, (edited by) The century of school: education of the twentieth century, New Italy, Florence, 1995.

${ }^{3} \mathrm{~L}$. Trisciuzzi, The integration of the disabled into the compulsory school. An Alternative Didactic Proposal, Lisciani \& Giunti Editore, Teramo, 1980.
} 


\section{Dictionaries}

Academy of Sciences of the Republic of Albania, (1976) Dictionary of Written Albanian Language

Academy of Sciences of the Republic of Albania, (1998) Për pastërtinë e gjuhës shqipe (On the Purity of Albanian Language)

Dhrimo Ali, Memushaj Rami, (2011) Dictionary of Written Albanian Language, Infobotues

Görlach Manfred, (2001) A Dictionary of European Anglicisms, Oxford University Press

Hornby A.S., (1981) Oxford Advanced Learner's Dictionary, Oxford University Press

\section{Journals}

Filipović Rudolf, (October 1961) The Morphological Adaptation of English Loan-Words in Serbo-Croat, Studia Romanica et anglica, Zagrabiensia

Jorgaqi Kristina, (1992) "A Challange for the Identification of the Italian Lexical Borrowings in the Modern Albanian Language", Studime filologjike (Phylogogical Studies Magazine), no. 1-2

Lafe Emil, (2004) Gjuha e medias - probleme dhe detyra, (Language of the Media - issues and tasks), 'Gjuha jonë'

Lilo R., (2004) "Vëzhgime rreth tipologjisë së huazimeve në shqipen e sotme" (Some observations on the typology of loans in Standard Albanian - Third Seminar on: "Loans in the Standard Albanian", University of Tirana, Faculty of Foreign Languages, Pegi

Lloshi Xhevat, (2011) Raste ndërhyrjesh të huazimeve nga anglishtja', (Some cases of English loan interventions in Albanian), Studime filologjike, no. 1-2

Shehu Haji, (2000) Rreth fjalëve angleze ose me prejardhje nga anglishtja në gjuhën e sotme shqipe, (On the English words or words of English origin in the Albanian language), International Seminar

Shehu Hajir, (2002) Rreth Anglicizmave në Mjetet e Sotme të Informimit Masiv, (On Anglicisms in the Media), Studime Filologjike, No 3-4

Shkurtaj Gjovalin, (2004) Drejtshkrimi dhe drejtshqiptimi në mediat e sotme të shkruara dhe të folura, (Writing and Pronuncing a Proper Albanian in the written and spoken press), Gjuha jonë

Shkurtaj Gjovalin, (2004) "Trysnia e Huaj dhe Qëndresa e Shqipes" (Foreign Pressure and the Resistance of Albanian Language) - Third Seminar: "On the Loans in the Standard Albanian", University of Tirana, Faculty of Foreign Languages, Pegi

Tupe E., (2007) Fjalë e struktura të huaja: (kundër)veprimi i shqipes, (Foreign words and structures: Albanian (counter) action), Studime filologjike, 1-2

\section{2-3 authors}

Fischer R., Pulaczewska H., (2008) Anglicisms in Europe: Linguistic Diversity in the Global Context, Cambridge Scholars Publishing

\section{4 or more authors}

Agalliu F., Angoni E., Demiraj Sh., Dhrimo A., Hysa E., Lafe E., Likah Ethem, (2002) Grammar of Albanian Language, I, II, Academy of Sciences of the Republic of Albania 